\title{
HUBUNGAN ANTARA STATUS GIZI DENGAN KADAR HEMOGLOBIN PADA IBU HAMIL TRIMESTER III
}

\author{
In The Third Trimester Pregnant Women \\ Sab'ngatun1, Ajeng Novitasari2 \\ STIKES Mamba'ul 'Ulum Surakarta \\ (sabngatun@yahoo.com)
}

The Relationship Between Nutritional Status And Hemoglobin Levels

\begin{abstract}
ABSTRAK
Latar Belakang : Ibu hamil yang mengalami status gizi kurang dengan ukuran lingkar lengan atas $<23,5 \mathrm{~cm}$ beresiko terjadi anemia, anemia selama kehamilan dapat bersesiko perdarahan pada masa persalinan dan berseiko melahirkan bayi dengan berat badan lahir rendah. Penelitian ini bertujuan untuk mengetahui hubungan antara status gizi ibu hamil dengan kadar hemoglobin pada ibu hamil trimester III.

Metode : Penelitian ini menggunakan metode survey analitik dengan pendekatan crossectional. Penelitian ini tidak menggunakan sampel tetapi menggunakan subyek penelitian yaitu seluruh ibu hamil trimester III di BPM Sri Suparti Boyolali.

Hasil : Status gizi ibu hamil mayoritas normal 22 responden (68.75\%), kadar hemoglobin mayoritas anemia 18 responden (56,25\%), terdapat hubungan antara status gizi dan kadar hemoglobin pada ibu hamil trimester III dengan nila $\mathrm{p}=0.009$ $<0.005$ pada taraf signifikan $5 \%$ dan nilai $\mathrm{X}_{2}$ hitung $=6,732>\mathrm{X}_{2}$ tabel $=4,619$.

Simpulan : ada hubungan antara status gizi dan kadar hemoglobin pada ibu hamil trimester III.
\end{abstract}

Kata kunci : status gizi, kadar hemoglobin, ibu hamil trimester III

\begin{abstract}
Background: Pregnant women who have less nutritional status with an upper arm circumference $<23.5 \mathrm{~cm}$ are at risk of anemia, anemia during pregnancy may be at risk of bleeding during labor and at risk of delivering a low birth weight baby. This study aims to determine the relationship between nutritional status of pregnant women with hemoglobin levels in pregnant women trimester III.

Method: This research use analytical survey method with crossectional approach. This research did not use sample but using research subject that is all pregnant mother of third trimester at BPM Sri Suparti Boyolali.

Result: Nutritional status of pregnant women majority normal 22 respondents (68.75\%), hemoglobin majority majority anemia 18 respondents (56.25\%), there is relationship between nutritional status and hemoglobin level in pregnant mother of trimester III with indigo $p=0.009<0.005$ at significant $5 \%$ and X2 count $=6.732>X 2$ table $=4,619$.

Conclusion: there is relationship between nutritional status and hemoglobin level in pregnant mother of trimester III.
\end{abstract}

Keywords: nutritional status, hemoglobin level, pregnant mother of trimester III 


\section{PENDAHULUAN}

Jumlah kasus kematian Bayi turun dari 33.278 di tahun 2015 menjadi 32.007 pada tahun 2016, dan di tahun 2017 di semester I sebanyak 10.294 kasus. Demikian pula dengan angka kematian Ibu turun dari 4.999 tahun 2015 menjadi 4912 di tahun 2016 dan di tahun 2017 (semester I) sebanyak 1712 kasus (Kemenkes, 2017).

Upaya penurunan angka kematian ibu (AKI) di Jawa Tengah merupakan indikator utama dalam pembangunan kesehatan, hasilnya melebihi target SDG's. AKI pada 2017 adalah 88,58 per 100 ribu kelahiran hidup. Dan mengalami penurunan empatbelas persen pertahun. Penurunan AKI di Jawa Tengah 88,58 per 100 ribu kelahiran hidup itu bahkan melampaui target SDG's yang menetapkan pada angka 90 per 100 ribu kelahiran hidup. Upaya ini tidak lepas dari program Jateng Gayeng Nginceng Wong Meteng yang diluncurkan Gubernur Jawa Tengah H Ganjar Pranowo SH MIP pada 2016 lalu di Surakarta. Program tersebut dilaksanakan dari hulu sampai hilir, lintas program dan lintas sektoral mulai dari primer sampai tersier. (Humas Jateng, 2018)

Angka kematian bayi (AKB) maupun angka kematian balita (Akaba) juga mengalami penurunan. Lima tahun yang lalu, AKB Jawa Tengah tercatat 10,41 per 1.000 kelahiran hidup. Pada 2017 sudah turun menjadi 8,93 per 1.000 kelahiran hidup. Sedangkan Akaba juga turun cukup signifikan dari sebelumnya 11,8 jadi 10,47 per 1.000 kelahiran hidup (Humas Jateng, 2018).

Penyebab kematian ibu, penyebab tertinggi kematian ibu di tahun 2016, 32 persen diakibatkan perdarahan. Sementara 26 persen diakibatkan hipertensi yang menyebabkan terjadinya kejang, keracunan kehamilan sehingga menyebabkan ibu meninggal. Penyebab lain adalah faktor hormonal, kardiovskuler, dan infeksi. Sedangkan penyebab kematian bayi usia 0-28 hari diantaranya berat bayi lahir rendah dan prematur, penyebab lain kematian bayi adalah sesak nafas dan infeksi. Penyebab kematian ibu dan bayi tersebut disebabkan kehamilan di bawah usia 20 tahun. Hamil dan bersalin di bawah usia 20 tahun sangat berisiko karena di usia ini rahim belum siap dijadikan tempat tinggal janin dan menjalani persalinan. Sehingga bisa menyebabkan berbagai komplikasi (Gustina, 2017).

Berdasarkan Survey Demografi dan Kesehatan Indonesia (SDKI) tahun 201210 persen remaja berusia 15-19 tahun di Indonesia telah menjadi ibu padahal kehamilan di bawah usia 20 tahun bisa menyebabkan resiko meningkatknya resiko abortus, persalinan premature dan BBLR, hipertensi dalam kehamilan, post partum blus, serta meningkatkan reisko kematian, hal ini disebabkan karena pada usia kurang dari 20 tahun perempuan belum siap untuk menghadapi kehamilan ditambah lagi pengetahuan yang kurang tentang kehamilan persalinan serta gizi ibu hamil. (Kompas. 2016)

Berdasarkan survey pementauan status gizi (PSG) tahun 2016 ibu hamil KEK sebanyak 16,2\%, kurangnya asupan makanan menjadi factor utama yang beresiko terjadinya kekurangan energy kronik ibu hamil. Hanya 26,3\% 
ibu hamil yang memenuhi kecukupan energy dan 29,3\% ibu hamil yang memenuhi kecukupan protein. Oleh sebab itu kurang energy dan protein itulah yang menajdi pencetus kejadian KEK pada ibu hamil. Pemerintah mempunyai kebijakan untuk mengatasi ibu hamil KEK tersebut dengan memberikan makanan tambahan pada ibu hamil dan memberikan tablet tambah darah minimal 90 tablet selama kehamilan (Kemkes. 2017).

Salah satu masalah gizi yang banyak terjadi pada ibu hamil adalah anemia gizi, yang merupakan masalah gizi mikro terbesar dan tersulit diatasi di seluruh dunia. WHO / World Health Organization melaporkan terdapat 52\% ibu hamil mengalami anemia di negara berkembang. Di Indonesia (Susenas dan Survey Depkes-Unicef) dilaporkan bahwa sekitar 4 juta ibu hamil separohnya mengalami anemia gizi dan satu juta lainnya mengalami kurang energi kronis (KEK). Ibu hamil yang mengalami KEK sebesar 16,2\% yang mendapatkan makanan tambahan 79,5\%, ibu hamil yang mengalami defisit protein $51,9 \%$. Sedangkan ibu hamil yang mendapatkan tablet tambah darah sebesar 40,2\%. (Kemkes. 2017)

Status gizi ibu, baik sebelum maupun ketika hamil merupakan faktor yang sangat berpengaruh terhadap hasil konsepsi. Jika status gizi ibu baik dan status kesehatannya selama hamil tidak buruk ( misalnya tidak menderita hipertensi ) serta tidak mempunyai kebiasaan buruk ( perokok atau pecandu alkohol ) maka status gizi bayi yang dilahirkannya juga baik. Wanita yang menderita malnutrisi sebelum hamil atau selama minggu pertama kehamilan cenderung melahirkan bayi dengan kerusakan otak dan sumsum tulang belakang karena sistem saraf pusat sangat peka pada 2 - 5 minggu pertama. Ibu penderita malnutrisi sepanjang minggu terakhir kehamilan akan melahirkan bayi dengan berat lahir rendah karena jaringan lemak banyak ditimbun selama trimester III (Arisman, 2008)

Masalah kesehatan ibu hamil di Indonesia, yang muncul akibat kekurangan asupan gizi adalah anemia pada kehamilan. (Sulistyoningsih, 2011). Gizi kurang pada ibu hamil dapat menyebabkan resiko dan komplikasi pada ibu antara lain: Anemia, perdarahan, berat badan ibu tidak bertambah secara normal dan terkena penyakit infeksi. Sehingga akan meningkatkan kematian ibu. Anemia dalam kehamilan ialah kondisi ibu dengan kadar hemoglobin dibawah 11 gr\% pada trimester I dan III atau kadar hemoglobin kurang 10,5 gr\% pada trimester II Muhlisin, 2016). Anemia dalam kehamilan dapat mempengaruhi kehamilan karena anemia dapat menurunkan daya tahan tubuh yang berakibat kematian janin dalam kandungan, abortus, cacat bawaan, Berat Badan Lahir Rendah. Pada persalinan dapat menyebabkan inertia uteri, ibu menjadi lemas sehingga menimbulkan partus lama. Sedangkan masa nifas dapat terjadi perdarahan dan pada keadaan ini tubuh tidak dapat mentoleransi seperti ibu sehat tidak menderita anemia hal kematian perinatal secara bermakna lebih tinggi (Manuaba, 2012).

Anemia merupakan masalah kesehatan dengan Prevalensi tertinggi pada Ibu Hamil. Tujuh dari sepuluh wanita Hamil di Indonesia mengalami Anemia. Data menunjukkan bahwa 83,6\% ibu hamil mengalami Anemia. 
Apabila seorang wanita mengalami anemia selama hamil, kehilangan darah pada saat wanita melahirkan, bahkan kalaupun minimal, tidak ditoleransi dengan baik, wanita beresiko membutuhkan tranfusi darah. Sekitar $80 \%$ kasus anemia pada masa hamil merupakan anemia tipe defisiensi besi (Sulistyoningsih, 2011).

Hasil studi pendahuluan yang dilakukan pada bulan Januari 2018 bahwa 3 ibu hamil trimester III mengalami anemia dan mempunyai Lila $<23,5 \mathrm{~cm}$ terdapat 2 ibu hamil. Di mana rata - rata kunjungan ibu hamil di BPM Sri Suparti Boyolali 30 - 40 ibu hamil setiap bulannya. Berdasarkan masalah di atas maka penulis tertarik mengambil judul Hubungan antara status gizi ibvu hamil dengan kadar hemoglobin pada ibu hamil trimester III di BPM Sri Suparti Boyolali.

\section{METODE PENELITIAN}

Penelitian ini merupakan penelitian survey analitik dengan pendekatan crossectional. Subjek penelitian ini adalah seluruh ibu hamil trimester III di BPM Sri Suparti Boyolali sebanyak 32 responden. Variabel dalam penelitian ini adalah variabel independen di sini adalah status gizi ibu hamil. Sedangkan variabel terikat atau dependen di sini adalah kadar hemoglobin ( $\mathrm{Hb}) \mathrm{ibu}$ hamil.

Alat yang digunakan dalam penelitian ini adalah pita ukur LILA dan alat pengukur kadar $\mathrm{Hb}$. Penelitian ini menggunakan metode pengumpulan data primer berupa hasil pengukuran lingkar lengan atas dan sekunder berupa hasil pemeriksaan kadar hemoglobin. Analisis data dalam penelitian ini menggunakan chi square.

\section{HASIL DAN PEMBAHASAN}

Tabel 1. Distribusi Frekuensi karakteristik responden berdasarkan umur dan gravida

\begin{tabular}{ccc}
\hline Karakteristik & Frekuensi & $\begin{array}{c}\text { Prosentasi } \\
\mathbf{\%}\end{array}$ \\
\hline Umur & 1 & 3,1 \\
$<20$ & 30 & 93,8 \\
$20-35$ & 1 & 3,1 \\
$>35$ & 32 & 100 \\
\hline Jumlah & 20 & 62.5 \\
Gravida & 12 & 37.5 \\
\hline Primigravida & 32 & 100 \\
\hline Multigravida & &
\end{tabular}


Tabel 2. Distribusi frekuensi status gizi responden

\begin{tabular}{lcc}
\hline Status Gizi & Frekuensi & $\begin{array}{c}\text { Prosentase } \\
\mathbf{\%}\end{array}$ \\
\hline Normal & 22 & 68.75 \\
Tidak Normal & 10 & 31.25 \\
Jumlah & 32 & 100 \\
\hline
\end{tabular}

Tabel 3. Distribusi frekuensi kadar hemoglobin responden

\begin{tabular}{ccc}
\hline $\begin{array}{c}\text { Kadar } \\
\text { Hb }\end{array}$ & Frekuensi & $\begin{array}{c}\text { Prosentase } \\
\text { \% }\end{array}$ \\
\hline Tidak & 14 & 43.75 \\
anemia & & \\
Anemia & 18 & 56.25 \\
Jumlah & 32 & 100 \\
\hline
\end{tabular}

Tabel 4. Tabulasi silang dan uji chi square antara status gizi dengan kadar $\mathrm{Hb}$ Ibu hamil

\begin{tabular}{|c|c|c|c|c|c|c|c|c|}
\hline & & \multicolumn{4}{|c|}{ Kadar Hb } & \multirow{2}{*}{$\begin{array}{c}\text { Tota } \\
1\end{array}$} & \multirow[t]{2}{*}{$\mathrm{X}^{2}$} & \multirow[t]{2}{*}{$\mathrm{P}$} \\
\hline & & anemia & $\%$ & $\begin{array}{c}\text { Tidak } \\
\text { anemia }\end{array}$ & $\%$ & & & \\
\hline Status & \multirow{4}{*}{$\begin{array}{l}\text { Tidak } \\
\text { normal } \\
\text { normal }\end{array}$} & 9 & 28.1 & 1 & 3.1 & 10 & \multirow{4}{*}{$\begin{array}{l}6.73 \\
2\end{array}$} & \multirow{4}{*}{$\begin{array}{l}.00 \\
9\end{array}$} \\
\hline \multirow[t]{2}{*}{ gizi } & & & & & & & & \\
\hline & & 9 & 28.1 & 13 & 40.7 & 22 & & \\
\hline Total & & 18 & 56.2 & 14 & 43.8 & 32 & & \\
\hline
\end{tabular}

Berdasarkan hasil pengujian dengan menggunakan alat analisis chi square dapat diketahui bahwa nilai x2 hitung adalah sebesar 6.732 adapun dengan $\mathrm{df}=1$ dan $\alpha=0,05(\mathrm{p}$ value $=0,009<0,05)$

Hasil nilainya lebih besar dari $\mathrm{X}_{2}$ tabel $=4.619$ dengan demikian dapat disimpulkan Ha diterima dan Ho ditolak yang artinya ada hubungan antara status gizi dengan kadar hemoglobin pada ibu hamil .

Berdasarkan tabel diatas dapat juga dilihat perhitungan nilai $\mathrm{P}$ value $=$ 0,009 maka $\mathrm{P}$ value $<0,05$ dengan demikian dapat disimpulkan bahwa Ha diterima dan Ho ditolak yang artinya ada hubungan yang signifikan antara status gizi dengan kadar hemoglobin pada ibu hamil.

Berdasarkan tabel 2 mayoritas responden mempunyai status gizi normal 22 responden (68.75\%). Salah satu faktor yang mempengaruhi status gizi adalah umur ibu. Berdasarkan tabel tersebut mayoritas status gizi normal dapat dilihat dari segi umur ibu 20 - 35 tahun. Untuk ibu hamil yang umurnya 20 - 35 tahun sudah matang dalam hal jasmani dan sosial sedangkan ibu hamil yang berumur $>35$ tahun dan $<20$ tahun merupakan faktor resiko yang paling besar pada saat mengalami kehamilan dan persalinan.

Hal ini sesuai dengan teori bahwa status gizi ibu baik sebelum maupun ketika hamil merupakan faktor yang sangat berpengaruh terhadap hasil konsepsi. Status gizi dipengaruhi oleh umur, berat badan, status kesehatan, 
status ekonomi, pengetahuan, kebiasaan dan pandangan wanita terhadap makanan, aktivitas, suhu lingkungan (Marni, 2013).

Dalam penelitian ini mayoritas memiliki status gizi normal dimana untuk mengetahui status gizi ibu hamil antara lain dengan mengukur lingkar lengan atas ( LILA ). Dikatakan status gizi normal apabila lingkar lengan atas ( LILA) $\geq 23,5 \mathrm{~cm}$ dan status gizi tidak normal $<23,5 \mathrm{~cm}$ (Waryana, 2010). Jika status gizi normal dan status kesehatannya tidak buruk ( tidak menderita suatu penyakit, misalnya hypertensi), serta tidak mempunyai kebiasaan buruk ( perokok atau pecandu alkohol ), maka status bayi yang dilahirkan juga baik. Wanita yang menderita malnutrisi sebelum hamil atau selama minggu pertama kehamilan cenderung melahirkan bayi dengan kerusakan otak dan sumsum tulang karena system saraf pusat sangat peka pada 2 -5 minggu pertama. Ibu menderita malnutrisi sepanjang minggu. Terakhir kehamilan akan melahirkan bayi dengan berat lahir rendah karena jaringan lemak banyak di timbun selama trimester III. (Arisman, 2008)

Berdasarkan tabel 3 menunjukkan mayoritas ibu hamil anemia sebanyak 18 responden (56.25\%). Pada kehamilan trimester III terjadi puncak hemodilusi sehingga perlu dilakukan pemeriksaan kadar hemoglobin untuk mengetahui anemia atau tidak. Seseorang dikatakan tidak anemia apabila kadar $\mathrm{Hb}$ normal $\geq 11$ gr \% dan dikatakan anemia apabila kadar $\mathrm{Hb}<11$ gr \%. Pada ibu hamil anemia disebabkan oleh suatu keadaan dimana jumlah eritrosit yang beredar atau konsentrasi hemoglobin menurun. Sebagai akibatnya, ada penurunan transportasi oksigen dari paru-paru ke jaringan perifer. Selama kehamilan anemia lazim terjadi dan biasanya disebabkan oleh defisiensi zat besi, sekunder terhadap kehilangan darah sebelumnya atau masukan zat besi yang tidak adekuat. Pertambahan volume darah sekitar 50\% untuk memenuhi kebutuhan pertambahan sirkulasi khususnya untuk plasenta, kebutuhan ibu dan anak. Jumlah sel darah merah juga meningkat, tetapi kenaikan sel darah merah tidak seimbang dengan kenaikan volume darah. Sebagai akibatnya anemia. Penurunan ini mulai terjadi pada umur kehamilan kehamilan 3-5 bulan dan mencapai batas terendah pada bulan ke 5-8. Kemudian naik dan kembali normal pada minggu ke 6 setelah melahirkan (Prawiroharjo, 2014).

Pengenceran darah (hemodilusi) pada ibu hamil sering terjadi dengan peningkatan volume plasma 30\%-40\%, peningkatan sel darah 18\%-30\% dan hemoglobin 19\%. Secara fisiologis hemodilusi untuk membantu meringankan kerja jantung. Hemodulusi terjadi sejak kehamilan 10 minggu dan mencapai puncaknya pada kehamilan 32-36 minggu. Bila hemoglobin ibu sebelum hamil berkisar 11 gr\% maka dengan terjadinya hemodilusi akan mengakibatkan anemia hamil fisiologis dan $\mathrm{Hb}$ ibu akan menjadi 9,5-10 gr\%. (Manuaba, 2012)

Tingginya anemia yang menimpa ibu hamil memberikan dampak negative terhadap janin yang di kandung dari ibu dalam kehamilan, persalinan maupun nifas yang di antaranya akan lahir janin dengan berat badan lahir rendah (BBLR), partus premature, abortus, pendarahan post 
partum, partus lama dan syok. factor antara lain; status (Prawirohardjo, 2014)

Anemia dalam kehamilan dapat mempengaruhi kehamilan karena anemia dapat menurunkan daya tahan tubuh yang berakibat kematian janin dalam kandungan, abortus, cacat bawaan, berat badan lahir rendah. Sebaiknya pemeriksaan kadar $\mathrm{Hb}$ dilakukan minimal dua kali yaitu pada Trimester I dan Trimester III, sehingga kekurangan Hb dapat dideteksi sejak dini dan dapat dilakukan pencegahan dengan memberikan tambahan zat besi. (Manuaba, 2012)

Berdasarkan hasil pengujian dengan menggunakan alat analisis chi square dapat diketahui bahwa nilai $\mathrm{x} 2$ hitung adalah sebesar 6.732 adapun dengan $\mathrm{df}=1$ dan $\alpha=0,05(\mathrm{p}$ value $=0,009<0,05)$

Hasil nilainya lebih besar dari $\mathrm{x} 2$ tabel $=4.619$ dengan demikian dapat disimpulkan Ha diterima dan Ho ditolak yang artinya ada hubungan antara status gizi dengan kadar hemoglobin pada ibu hamil .

Berdasarkan tabel 4 dapat juga dilihat perhitungan nilai $P$ value $=0,009$ maka $\mathrm{P}$ value $<0,05$ dengan demikian dapat disimpulkan bahwa Ha diterima dan Ho ditolak yang artinya ada hubungan yang signifikan antara status gizi dengan kadar hemoglobin pada ibu hamil.

Dari table 4 bisa disimpulkan bahwa ibu dengan staus gizi tidak normal mayoritas akan mengalami anemia 9 responde $(28,1 \%)$ sedangkan ibu dengan status gizi normal mayoritas tidak mengalami anemia 13 responden $(40,7 \%)$

Hubungan antara status gizi dan kadar hemoglobin pada ibu hamil dapat diketahui bahwa ibu hamil dengan status gizi tidak normal dan menderita anemia sebanyak 9 ibu hamil sedangkan ibu hamil dengan gizi normal dan tidak menderita anemia sebanyak 9 ibu hamil.

Hal ini sesuai dengan teori bahwa status gizi akan mempengaruhin kadar hb, jika ibu dengan status gizi kurang maka akan beresiko terkena anemia sedangkan ibu dengan staus gizi normal tidak beresiko terjadi anemia. jika seseorang status gizinya rendah (kekurangan karbohidrat dan protein) kemungkinan akan menurunkan kadar $\mathrm{Hb}$ dan meningkatkan resiko terjadinya anemia (Almatsier, 2011).

Faktor yang mempengaruhi KEK pada ibu hamil diantanya pendidikan ibu, perilaku, pola konsumsi, usia ibu, jarak kehamilan, paritas, kenaikan berat badan, dan penyakit infeksi. (Supariasa, 2013).

Salah satu faktor yang mempengaruhi status gizi dan kadar hemoglobin adalah status ekonomi. Dimana seorang ibu hamil sangat membutuhkan asupan gizi yang sangat banyak, tetapi dengan keadaan ekonomi yang tidak memungkinkan, maka kurang mendapatkan gizi yang seharusnya. Sehingga bisa menyebabkan kejadian anemia. Status gizi adalah keadaan tubuh sebagai akibat konsumsi makanan dan penggunaan zat-zat gizi. Dibedakan antara status gizi buruk, kurang, baik dan lebih.(Almatsier, 2011) Status gizi dibagi 2 macam yaitu status gizi normal dan malnutrition. Status gizi yang normal 
yaitu keadaan tubuh yang mencerminkan keseimbangan antara konsumsi dan penggunaan gizi oleh tubuh (adekuat). Sedangkan malnutrition yaitu keadaan patologis akibat kekurangan atau kelebihan secara relatife maupun absolute satu / lebih zat gizi (Almatsier, 2011)

Kurus dan gemuknya seseorang mencerminkan bagaimana asupan nutrisi orang tersebut, terutama karbohidrat sebagai sumber utama energi, serta protein dan lemak. Jika seseorang memiliki status gizi buruk atau kurang, maka kemungkinan besar orang tersebut menderita KEK (Kurang Energi Kalori) dan KEP (Kurang Energi Protein). Hal itu menandakan bahwa orang tersebut asupan karbohidratnya rendah, yang berarti bahwa orang tersebut beresiko mengalami anemia.(Waryana, 2010)

Karbohidrat sebagai sumber kalori utama bagi tubuh, 1 gram karbohidrat setara dengan 4 kalori. Karbohidrat berfungsi untuk mencegah pemecahan protein tubuh yang berlebihan, yang berakibat kepada penurunan fungsi protein sebagai enzim dan fungsi antibodi. Bila karbohidrat makanan tidak mencukupi, maka protein akan digunakan untuk memenuhi kebutuhan energi dengan mengalahkan fungsi utamanya sebagai zat pembangun. Sebaliknya, bila karbohidrat makanan mencukupi, protein terutama akan digunakan sebagai zat pembangun. (Almatsier, 2011)

Protein merupakan zat yang paling penting dalam setiap organisme, bagian terbesar tubuh sesudah air (1/5 bagian tubuh). Semua enzim, berbagai hormon, pengangkut zat-zat gizi dan darah, matriks intraseluler adalah protein. Protein berfungsi dalam pembentukan ikatan-ikatan esensial tubuh. Hemoglobin, pigmen darah yang berwarna merah dan berfungsi sebagai pengangkut oksigen dan karbondioksida adalah ikatan protein. Jadi protein merupakan salah satu unsur pembentuk hemoglobin. Jika seseorang kekurangan protein, maka pembentukan hemoglobinpun akan terhambat sehingga kadar hemoglobin dalam tubuhnya akan menurun. Itulah sebabnya mengapa jika seseorang status gizinya rendah (kekurangan karbohidrat dan protein) kemungkinan akan menurunkan kadar $\mathrm{Hb}$ dan meningkatkan resiko terjadinya anemia (Almatsier, 2011).

Penelitian yang dilakukan oleh Marlapan (2013) bahwa hasil analisa hubungan antara status gizi dengan kejadian anemia pada ibu hamil menggunakan uji statistik chi square dengan nilai $0,005<\alpha 0,05$. Hipotesis Nol $\left(\mathrm{H}_{0}\right)$ ditolah berarti ada hubungan antara status gizi dengan kejadian anemia pada ibu hamil. Nilai Odds ratio/ OR menunjukkan 3,109 dimana ibu hamil dengan status gizi beresiko KEK mempunyai resiko 3 kali lipat lebih besarmengalami anemia daripada ibu hamil dengan staus gizi tidak beresiko KEK.

Penelitian sejalan dengan penelitian yang dilakukan oleh Mulyani (2013) terdapat hubungan yang signifikan antara status gizi dengan kadar $\mathrm{Hb}$ pada ibu hamil dengan $p$ value $=0,006<0,05$, dan nilai $r=0,546$ maka kekuatan hubungan tersebut sedang karena nilai $r=0,542$ ( berada diantara 0,26 $0,55)$, sifat hubungan tersebut positif yang artinya semakin baik status gizi maka semakin baik pula kadar $\mathrm{Hb}$. 
Penelitian lain pernah dilakukan di Puskesmas Magelang Selatan Kota Magelang dengan sampel 29 ibu hamil menggunakan uji Kendal tau dengan SPSS forwindows 16, didapatkan hasil bahwa ada hubungan antara indeks massa tubuh (IMT) dengan kadar hemoglobin pada ibu hamil di Puskesmas Magelang Selatan pada tahun 2010.( Setyaningsih, 2010)

Penulis menyadari sepenuhnya dalam penelitian ini masih banyak kekurangan dan kelemahan, antara lain penelitian yang dilakukan hanya untuk mengetahui hubungan status gizi dengan kadar hemoglobin pada ibu hamil tanpa meneliti faktor luar yang menyebabkan kejadian anemia dan juga klasifikasi anemia belum dipertimbangkan.

\section{SIMPULAN DAN SARAN}

\section{Simpulan}

Berdasarkan hasil penelitian tentang hubungan status gizi dengan kadar hemoglobin pada ibu hamil trimester III di BPM Sri Suparti Boyolali maka dapat ditarik kesimpulan Karakteristik ibu hamil di BPM Sri Suparti Boyolali berdasarkan umur mayoritas berumur 20 - 35 tahun sebanyak 30 ibu hamil $(93,8 \%)$, dan berdasarkan gravida mayoritas primigravida sebanyak $20 \mathrm{ibu}$ hamil $(62,5 \%)$. Ibu hamil di BPM Sri Suparti Boyolali mayoritas dengan status gizi normal sebanyak 22 ibu hamil $(68,75 \%)$. Ibu hamil di BPM Sri Suparti Boyolali mayoritas anemia sebanyak 18 ibu hamil (56,25 \%) . Ada hubungan antara status gizi ibu hamil dengan kadar hemoglobin pada ibu hamil BPM Sri Suparti Boyolali.

\section{Saran}

Bagi Ibu diharapkan ibu hamil ibu hamil trimester ketiga selalu memperhatikan asupan gizi seimbang dan rutin mengkonsumsi tablet tambah darah. Bagi Bidan diharapkan dapat melakukan pengecekan kadar HB rutin pada trimester III dan memonitor ibu hamil yang mengalami anemia dan KEK. Bagi Peneliti Selanjutnya diharapkan dapat mengembangkan penelitian ini dengan menambah variabel berat badan bayi yang dilahirkan ibu yang mengalami anemia dan KEK.

\section{DAFTAR PUSTAKA}

Arisman. 2008. Gizi Dalam Daur Kehidupan. Jakarta. EGC.

Almatsier, S. 2011. Prinsip Dasar Ilmu Gizi. Jakarta. Gramedia.

Gustina, Eni. 2017. Penyebab tingginya angka kematian ibu dan bayi di Indonesia https://www.viva.co.id/gaya-hidup/kesehatanintim/892600-penyebab- tingginya-angka-kematian-ibu-dan-bayi-diindonesia diakses tanggal 19 maret 2018

Humas Jateng. 2018. Penurunan AKI di Jateng lampaui terget SDGs. https://jatengprov.go.id/publik/penurunan-aki-di-jateng-lampauitarget-sdgs/ diakses tanggal 19 Maret 2018. 
Kemenkes RI, 2017. Capaian Kinerja Kemenkes RI tahun 2015-2017. http://www.depkes.go.id/article/view/17081700004/-inilah-capaiankinerja-kemenkes-ri-tahun-2015--2017.html diakses tanggal 19 Maret 2018

Kompas, 2016. Resiko Kehamilan Di Bawah Usia 20 Tahun. Kompas.com https://health.kompas.com diakses tanggal 20 maret 2018

Kemkes. 2017 Inilah hasil Pementauan Status Gizi (PSG) 2016. https://sehatnegeriku.kemkes.go.id diakses tanggal 20 maret 2018

Manuaba. 2012. Ilmu Kebidanan, Penyakit Kandungan dan Keluarga

Berencana untuk Pendidikan Bidan. Jakarta. EGC.

Marlapan, Sandrayayuk. 2013. Hubungan Status Gizi Dengan Kejadian Anemia Pada Ibu Hamil Di Wilayah Kerja Puskesmas Tuminting Kec. Tuminting Kota Manado. ejournal keperawatan (e-Kp) Volume 1. Nomor 1. Agustus 2013 https://media.neliti.com/media/publications/106817-ID-hubunganstatus-gizi-dengan-kejadian-ane.pdf diakses tanggal 20 Maret 2018

Marmi. 2013. Gizi Dalam Kesehatan Reproduksi. Yogyakarta. Pustaka Pelajar. Mulyani, Sri , 2013. Hubungan antara status gizi dengan kadar hemoglobin pada ibu hamil trimester II di puskesmas badarharjo semarang utara. http://ejournal.stikestelogorejo.ac.id/index.php/ilmukeperawatan/arti cle/viewFile/143/168 diakses tanggal 21 Maret 2018

Prawirohardjo, Sarwono. 2014. Ilmu Kebidanan. Jakarta : Bina Pustaka Prawirohardjo, Sarwono. 2014. Ilmu Kandungan. Edisi ketiga Jakarta : Bina Pustaka

Sulistyoningsih. 2011. Gizi Kesehatan Ibu dan Anak. Yogyakarta. Graha Ilmu.

Sri Mulyani,2013. Hubungan status gizi dengan kadar hb pada ibu hamil trimester II di puskesmas Bandarharjo semarang utara.

Http://download.portalgaruda.org/article.php?Article $=183493 \& \mathrm{val}=63$ 78\&title=HUBUNGAN\%20ANTARA\%20STATUS\%20GIZI\%20DENGAN \%20KADAR\%20HEMOGLOBIN\%20PADA\%20IBU\%20HAMIL\%20TRIM ESTER\%20II\%20DI\%20PUSKESMAS\%20BANDARHARO\%20SEMARAN G\%20UTARA diakses tanggal 22 Maret 2018

Waryana. 2010. Gizi Reproduksi. Yogyakarta. Pustaka Rihama. 
